Article

\title{
Collaborative Concession in Food Movement Networks: The Uneven Relations of Resource Mobilization
}

\author{
Joshua Sbicca * (1), India Luxton, James Hale and Kassandra Roeser \\ Department of Sociology, Colorado State University, Fort Collins, CO 80523, USA; \\ india.luxton@colostate.edu (I.L.); jameswhalephd@gmail.com (J.H.); kroeser@rams.colostate.edu (K.R.) \\ * Correspondence: j.sbicca@colostate.edu
}

Received: 15 February 2019; Accepted: 14 May 2019; Published: 21 May 2019

\begin{abstract}
How do food movements prioritize and work to accomplish their varied and often conflicting social change goals at the city scale? Our study investigates the Denver food movement with a mixed methods social network analysis to understand how organizations navigate differences in power and influence vis-à-vis resource exchange. We refer to this uneven process with the analytical concept of "collaborative concession". The strategic resource mobilization of money, land, and labor operates through certain collaborative niches, which constitute the priorities of the movement. Among these are poverty alleviation and local food production, which are facilitated by powerful development, education, and health organizations. Therefore, food movement networks do not offer organizations equal opportunity to carry out their priorities. Concession suggests that organizations need to lose something to gain something. Paradoxically, collaboration can produce a resource gain. Our findings provide new insights into the uneven process by which food movement organizations-and city-wide food movements overall—mobilize.
\end{abstract}

Keywords: food movement; alternative food; local food; social network analysis; social movements; resource mobilization; mixed methods; alliance building

\section{Introduction}

Food movements in cities across the world organize around an array of food system problems to create change at a local level. Food activists work across many interests, from increasing the number of food retail spaces, micro value-added enterprises, community gardens, healthy food consumption, institutional purchasing of local food, and access to land for urban food production, to reducing food insecurity, the consumption of sugary beverages, and food waste. However, the process of changing the food system is not value-neutral; hegemonic worldviews and political economies can blunt the potential of food activism [1,2]. Nor is said activism free from differences in power and privilege; the capacity to set agendas and capture resources flows often reflects entrenched social inequalities $[3,4]$. Given this context, our study asks and answers two questions. First, how do we understand the uneven networked process by which certain food movement priorities become codified? Second and relatedly, how do food movement organizations collaborate to achieve their goals as part of a larger movement?

In order to understand food movements, we can look more broadly at the social science study of social movements. Social movements signify to the public collective action on some change agenda, but the relationships among the constituent parts of a social movement hidden from public view reflect a heterogeneous process of mobilization [5,6]. Collaborative subsets, resource sharing patterns, organizational segregation, and ideological difference are only a few of the practices that explain who has the influence to direct the goals and outcomes of a social movement $[7,8]$. Social network 
analysis is particularly well suited to understand the contested dimensions of social movement mobilization, including the structuring and emergent qualities of network ties [9,10]. Networks are viscous, with a mix of linkages that bind and divide people and organizations, say over questions of purpose or identity. However, to say that networks are the sole driver of action or that they are the outcome of action is to miss the practical significance of interpersonal or interorganizational relations to the experience of movement mobilization [11]. A relational understanding of a social movement, which is always networked in some fashion, can account for opportunities, constraints, cohesions, and divisions as part of the process of social change.

We argue that for those of us who study the food movement, it is vital to specify how networks matter to interorganizational dynamics. With hundreds of case studies of food movement organizations and campaigns, the diversity of the movement is clear. However, our understanding of how communities self-organize into networks at the meso level of cities and the implications for food movements are muddy. Partially in response, there is a rapidly growing body of research on food movement networks $[12,13]$. Our contribution is to offer a relational focus that can capture the work that food movement networks carry out, specifically among differently situated organizations.

Our study investigates the Denver food movement at a municipal scale with a mixed methods social network analysis to understand how organizations navigate differences in power and influence vis-à-vis resource exchange. We refer to this process with the analytical concept of "collaborative concession". Food movement organizations make decisions, which reflect and structure food movement networks, based on resource assets and deficits. Reflecting movement-wide trends, organizations accommodate each other, often in cooperative ways, based on uneven resource balances of money, land, and labor [14]. The absence of such concessions would be an even collaborative network. However, organizations come into collaborations with different resource levels and types. Food movement networks do not offer organizations equal opportunity to carry out organizational priorities. Concession suggests that organizations need to lose something to gain something. Paradoxically, collaboration can produce a resource gain. This has ramifications for how food movement organizations, and the movement overall, operate.

We find that in Denver, the configuration of networked food movement organizations can be both empowering and constraining. This is because collaboration is structured around relationships between organizations that vie for movement influence and yet are disciplined by their resource needs. We trace the process of collaborative concession and discover that the strategic resource mobilization of money, land, and labor revolve around certain collaborative niches that are more central to the network and drive the overall priorities of the movement. Among these are local food production and poverty alleviation, which are facilitated by powerful development, education, and health organizations. Instead of viewing food movement organizations as part of a networked structure that determines their resource needs, or as isolated nodes free from resource constraints, we see this as a contested and uneven process of movement mobilization.

\section{Literature Review: Food Movement Networks and Collaborative Mobilization}

While scholars tend to use the term alternative food networks when referring to the organized clustering of people and organizations around food system change, we prefer food movement networks. First, referring to the food movement is more encompassing than alternative food. The latter is limiting given its typical association with focusing strictly on the object of food and how people mobilize to develop "alternatives" to the conventional food system (e.g., farmers markets and fair-trade products) [15]. Looking at the food movement goes further by accounting for how activists organize at various intersections of food and social problems (e.g., labor exploitation, health, poverty) [16]. Second, a focus on social movements more explicitly accounts for modes of collective action and grassroots mobilization methods that have the intent to challenge power holders in some way [17]. Alternative food networks overdetermine the market as movement, thus circumscribing the political as consumption. Last, and relatedly, there is a longstanding literature on food movements that 
engages with its range of approaches along the alternative to oppositional and neoliberal to radical continuum [1,18-20]. Unpacking this difference through the lens of networks can account for a more diverse set of food system change activities and relationships.

If we understand social movements as collectivities acting to defend or challenge authority within some social formation, then this can encompass a range of networked activities and power dynamics between differently situated interests. As Diani [10] noted, the conventional view of networks is that they consist of "sets of nodes, linked by some form of relationship, and delimited by some specific criteria" (p. 6). This view is open enough to account for many aspects of a social movement. Be it to explain emergence and participation or social movement organization and interaction with institutions, network analysis is increasingly used to study social movements [9].

The language of networks assumes that there is some bond that holds a group together, albeit with differences with respect to the centrality of actors and cohesion between actors within a network. Seeing as networks of organizations make up many social movements, we need to consider the content of the ties that bind and divide [21]. Asking about collaboration is one key way to unpack such relationships and delimitations [22]. After all, working with others is often necessary to accomplish broader movement goals [23]. However, this is not an inherently smooth process. Inequalities in the structure of the network that shape relations between central and peripheral organizations can drive certain kinds of priorities and set the movement's agenda.

Within the literature on alternative food networks and food movements, there are several approaches to discussing networks, which have implications for understanding collaboration. One body of literature discusses alternative ways of organizing and valuing the exchange of food, say through farmers markets, community-supported agriculture, cooperatives, or solidarity economies $[15,24,25]$. Another approach is through the lens of local food systems and food sheds; this approach tries to understand their networked attributes with respect to how consumers and producers relate to each other within a particular place [26-28]. While these first two approaches offer some differences, they are similar insofar as collaboration entails a strong market focus, although there is some debate about what constitutes an "alternative food network" [29]. A third promising development looks at food movement networks as assemblages, which accounts for the greater diversity of the movement, and inherently centers relations [13]. It is this last approach that opens the analysis of collaboration to forms of food-based social change that encompass a range of organizational types and activities across economic, political, and social fields.

Again, our position is that food movement networks more accurately reflect the range of activities happening at a grassroots level beyond a strictly market lens. Communities self-organize for food system change in many ways. Our intervention entails pushing the analysis of food movement networks to explain the scale of action, attributes of collaboration within networks, and the uneven constellation of organizational relations due to differences in resources and network position.

\section{Resource Exchange, Empowerment, and Constraint}

That social movements need or use resources to advance their cause is generally taken as a given [7]. How social movements come to obtain, use, share, and lose resources is another matter. This is pressing when activists face structural disadvantages and develop strategic alliances to increase the level and flow of resources [30]. This process is quintessentially collaborative concession. Food movement networks offer a relevant study of how organizations strategize to overcome the disadvantages of working individually to accomplish goals. Given the entrenched structure of the food system, the food movements pool efforts to shift practices to come in line with other values besides profit [31,32]. Yet, the work of sustaining a diverse food movement comes with asymmetries in how resources influence an organization's network position and capacity [33]. So, while movements organize through different resource exchanges, the constituent forms of collaboration can draw boundaries that condition activism [34]. 
At the scale of the city, money, land, and labor are key contested resources within food movements $[20,25]$. These resources are in short supply, so their inequitable distribution produces uneven outcomes [35]. When organizations possess money, land, and labor and can exchange them through collaboration, this can empower new initiatives and constrain resource-poor organizations by influencing an initiative's vision and parameters.

First, perhaps the most obvious resource is money. This is in short supply for food movement participants, whether one works for profit or non-profit initiatives. It is also a resource that is inequitably distributed within the food movement $[4,36,37]$. On the one hand, new alternative food market entrants must compete with engrained food supply chains and systems to sell their products. This is not only a matter of offering a distinct product that consumers will value, but also developing the proper relationships to get the food onto people's plates [38]. In brief, finding the startup capital and profitable market niche is challenging. On the other hand, food activists with a social mission often rely on the largesse of others [39]. The associated monetary rewards ebb and flow with broader economic conditions and political proclivities. Whether the goal is to feed hungry people or expand culinary arts, food activists will develop collaborations that share the costs of an initiative. Given these economic pressures, the need for land and labor become two typical resource constraints that drive collaborative concession.

Many interests compete for land in cities, especially in the context of gentrification [40]. This puts food movements in the difficult position of assessing how to both produce food and develop new spaces of consumption in line with values that often run counter to the pressures of capitalist urbanization to maximize profit [41,42]. In practice, organizations must strategize ways to access land for their work. For organizations engaged in urban agriculture, this is especially challenging as food production can rarely compete with housing or upscale new retail [43]. Urban agriculture sits uneasily with market incentives to make money, which can mean reducing land access costs by collaborating with developers and institutions such as schools, churches, or businesses. While an organization may be able to accomplish aspects of their mission by collaborating to access land, this may be short-lived without long-term land tenure, especially as such projects face neoliberal incentives to fill in for providing social welfare with far less resources than local government [20]. Therefore, the nature of collaboration varies. It could mean, for example, that in exchange for land, an urban agriculture organization (i) valorizes a place, thus making it attractive to outsiders, (ii) supports the educational mission of a school to skill their students in gardening, or (iii) land banks a property until a landowner can find a buyer.

Last, non-profits predominate in the food movement. One proxy for the prevalence of non-profits in the food movement is that $37 \%$ of food policy councils in the United States (US) are either housed in a non-profit organization or are an independent non-profit organization (about one-third are housed in government and the rest are grassroots coalitions) [44]. Many non-profits run on small budgets and rely on volunteers and exchange undercompensated labor for access to economic, political, and social spaces that help advance an initiative. Similar to other alternative food initiatives, there is the pressure to self-exploit and frame precarious work in moral economy terms, thus presenting advantaging to those with class and racial privileges to engage and therefore setting the parameters of the food movement $[45,46]$. In the case of urban agriculture, it is well documented that the organizations doing this work are asked to accomplish many tasks, but with minimal support, and that there are challenges to avoiding exploitative work $[47,48]$. Since labor is one of the key resources that food organizations can use to collaborate with others, it can serve many purposes. Although exchanging labor-say by volunteering to glean fruit or collect wasted bagels to distribute free to a food bank-can be an empowering experience for those involved, it can also funnel an organization into practices that rely on undercompensated labor. Without economic autonomy, food movement organizations find themselves at the whims of influential network actors that will only collaborate if the costs of doing so are low. Resource-poor organizations can internalize this pressure with poor labor practices.

Taken together, understanding the exchange of money, land, and labor helps explain how a food movement network self-organizes through collaborative concession to accomplish discrete 
goals, which reveals fissures between differently positioned organizations. These power differences reflect varying degrees of influence as well as the priorities and underlying values driving the larger movement [49]. Indeed, while food movements may help foster and reflect a collective "food activist" identity, certain organizations have more influence than others to channel activism. The language of foundations and business and government funders, as well as any organization that occupies a central network location due to the resources it can offer, creates incentives for more peripheral food movement organizations to shape their mission accordingly [50]. Looking at the change over time in food movement priorities reveals the narrative and ideological dimension of structuring what is "appropriate" food activism. Should the focus be on "local food" such as "farmers markets", "community supported agriculture", and "farm-to-table", combatting "food deserts" and fighting "obesity", putting a "food truck" on every corner, digging up an abandoned lot for a "community garden", or redistributing "food waste" to combat "food insecurity"?

For organizations with a long history, large budget, and paid staff, it is easier to set the agenda of the food movement. They can also play a gatekeeping role that mediates resource flows between more structurally advantaged groups, such as funders and landowners, and those reliant upon their resources to maintain or expand food activism. Given that money, land, and labor are meant to accomplish some movement task, initiative, or campaign, the overall effect can limit strategic visions, radical commitments, or creativity. In practice, this means that food movements self-organize into networks despite power differences between organizations. The differences, while constraining, also avail more participants in the movement to collectively act toward some end. As we present below, this process operates in Denver through certain collaborative niches that represent the priorities of the food movement and how they relate to resource exchanges. The tension between differently situated organizations is ultimately generative of collective action.

\section{Methods}

\subsection{Denver as a Site to Explore Food Movement Networks}

The city has long been a site to investigate broader social processes, problems, and social change efforts [51-54]. As the city pertains to the food movement, activists are organized locally to create more environmentally sustainable and socially just food systems [48]. Denver is a mid-size city of slightly over 700,000 people (all these statistics come from the American Community Survey Five-Year Estimate for 2013-2017). As of 2017, 53.6\% of the population is white, 30.5\% is Latinx, 9.2\% is African American, $3.5 \%$ is Asian, and $0.5 \%$ is Native American. Economically, $15.1 \%$ of residents live in poverty, while the unemployment rate currently hovers around 3\%. According to Massachusetts Institute of Technology's Living Wage Calculator, a single person would need to make $\$ 12.95$ or $\$ 29,936$ to support themselves. At least $20 \%$ of households do not make this much money a year. As an increasingly expensive city to live in as wealthier (and often white) newcomers replace long-time residents who can no longer afford to live in Denver, the city has sought ways to take care of people's basic needs and create jobs.

Civic, business, and political interests have identified food as one sector to help develop the city more equitably, as reflected in 2017 in the Denver Food Vision. This planning document was produced through a participatory process of meeting with residents in each City Council District and with key industry and food movement groups. With a series of discrete goals organized around the themes "inclusive", "healthy", "vibrant", and "resilient", the policy language plans to remake food systems in line with other cities around the United States [55]. This includes typical commitments to addressing food access issues, dietary disparities, and reskilling in food preparation and production, and supporting the economic development of local food supply chains. Therefore, how the food movement mobilizes in Denver can illuminate similar patterns in other cities throughout the United States, especially as it relates to institutionally sanctioned food politics. 


\subsection{Research Design, Data Collection, and Data Analysis}

We combine qualitative and quantitative research methods to explain interorganizational relations in Denver's food movement network. These include interviews, participant observation, and social network analysis. By triangulating between and moving iteratively through these methods and data, we examine the structure of the network, as well as detail qualitatively how this relates to the mechanisms that shape collaborative concessions.

Two sets of qualitative data inform this paper. The first comes from authors one, two, and four, and was collected between 2015-2017. This entailed 67 interviews representing 64 organizations. In these interviews, we asked about organizational history; local political, economic, and environmental contexts; access to land and space; questions of gender, ethnicity, and race in relation to their work; pressing problems in the food system; to what degree participants felt their organization was working on solving the aforementioned food system problems; and work in coalitions and other collaborative relationships with food movement organizations. Of note for this article, and based on our reading of the literature, are the questions we asked about the roles of money, land, and labor in organizations' work and collaborations.

The second qualitative data set is from research conducted by the third author, which was collected between 2005-2015. This includes 10 years of participation in Denver food movement networks and 52 interviews representing 40 organizations collected in 2013. Interviews sought to understand various resource barriers to urban agriculture collaboration according to various capitals. Although this interview guide was different from the one used in the aforementioned project, similar and complementary themes arose through the analysis. Both sought to understand important characteristics of collaboration. The second data source also helped confirm themes from interviews with the same and different representatives from organizations. The participation included volunteering with organizations as a laborer, researcher, facilitator, and builder of organizational capacity. Taken together, this researcher helped ground the analysis in the history and common practice of the Denver food movement. Triangulating the first and second qualitative data sources and using the analytical method described below established salient themes about food movement collaborations in Denver.

In total, the interviews represent 89 distinct organizations and 105 distinct people. We give all respondents and organizations pseudonyms per the informed consent forms they signed. The demographics of these participants by race and ethnicity are $81 \%$ White, $8 \%$ African American, $8 \%$ Latinx, $2 \%$ Asian, and $1 \%$ Native American; by sex, they are $53 \%$ male and $47 \%$ female. Reflecting a wide range of food activism, our sample includes farmers, gardeners, food retail professionals, vegans, food justice organizers, dietary health advocates, anti-hunger representatives, extension officers, and others working in organizations that focus explicitly on food.

The first, second, and fourth authors split up coding the interviews from the first project. Wanting to draw out themes relevant to the social network surveys, the team focused on collaboration, partnerships, and relationships. We coded interviews using NVivo 11, which is a data management tool that allows for the organization and analysis of qualitative data. We met weekly over a three-month period to discuss our findings, refine our coding, and increase our intercoder reliability. We wrote memos throughout this process to document the evolving themes, analysis, and questions regarding the nature and extent of collaboration in the Denver food movement. After completing the first round of coding, we drafted memos on our codes. From there, the first, second, and fourth author began to meet biweekly to further compare and analyze patterns of collaboration, as well as better understand the exchange of resources among organizations. Therefore, we started to integrate insights and data from the third author, which helped triangulate and nuance the themes of collaboration and the resource exchange of money, land, and labor. For the data analysis in the second project, the third author listened to and summarized interviews and then organized statements related to organizational collaborations and tensions. Despite the limitation that both datasets were not coded in the same way, the robustness of the first dataset and analysis, team meetings, the breadth of our sample, along with the participatory data, still aided in confirming and grounding themes in particular working 
examples that spoke back to the structure of the social network. To mitigate bias, over the course of both research studies, we regularly compared and integrated similar data, confirmed/disconfirmed emergent themes with informants, reflected together on developing key concepts, and iteratively engaged with relevant literature.

For our social network analysis purposes, this paper also relies on 59 social network surveys collected as part of the first project identified above. We asked participants in interviews to fill out the survey either on paper or online via Qualtrics. We also collected surveys by identifying organizations within the network that we had not interviewed nor had social network survey responses. After identifying 100 organizations, we recruited representatives to take the survey on Qualtrics. In our data clean up, we eliminated organizations that were outside of our network boundaries as well as condensed multiple respondents from a single organization. We defined our network boundaries as (1) being actively engaged in food system change work in Denver; and (2) as being geographically limited to working in or directly serving Denver. Additionally, the network focuses on answers to questions about the stated collaboration networks of respondents' organizations. Out of the 89 organizations represented in our interview sample, 11 did not complete a social network survey or show up in the social network survey responses.

Ego network data is commonly collected using survey questions that ask respondents to list the people with whom they share a particular relation [56]. Our survey asked participants to identify the top issue areas of their organization's work, existing local organizational collaborations and partnerships, funding sources, and perceived allies in the national food movement. We put ego-network responses into an attribute file that consisted of information regarding the type of organization (non-profit, business, government, education, grassroots, community organization), the target beneficiary (low-income people, public, private, food professionals, and farmers), and a distillation of the question about issue area to develop what we call a "collaborative niche". We focus most in this paper on the collaborative niche, which is simply the role that an organization plays in the context of networked food movement partnerships. It reflects the specific kind of work or food system change emphasis that an organization brings into a collaboration (Table 1).

Table 1. Collaborative Niche.

\begin{tabular}{l}
\hline \multicolumn{1}{c}{ Collaborative Niche } \\
\hline $\begin{array}{l}\text { Development: organizations engaged in activities related to urban planning, real estate development, financing } \\
\text { business, and/or foundations }\end{array}$ \\
\hline Education: organizations and institutions that center on education \\
\hline $\begin{array}{l}\text { Food retail: organizations that are working in the commercialization of food such as restaurants, cafes, farmer's } \\
\text { markets, and local grocers }\end{array}$ \\
\hline Health: organizations that focus primarily on health in relation to food, especially as it pertains to diet \\
\hline $\begin{array}{l}\text { Local food production: organizations involved in the production of food such as urban farms and community } \\
\text { gardens }\end{array}$ \\
\hline $\begin{array}{l}\text { Poverty alleviation: organizations working to intervene in the experience of poverty, especially by increasing } \\
\text { access to healthy and affordable food, and providing other economic and social services }\end{array}$ \\
\hline
\end{tabular}

After completing our qualitative data analysis, we examined the structure of the collaboration network. We loaded spreadsheets that contained the respondents' reported collaborations and our attribute data into UCINET, which is social network analysis software that allows for network visualization and calculating quantitative network measures [57]. For visualization purposes, we loaded final social network diagrams into Visone, which is social network analysis software with high-caliber visualization. Our data analysis of the network entailed identifying the most common collaboration codes, which we used to draft memos posing working hypotheses about the structure of the network and patterns of issue area collaboration. This, along with social network literature on centrality measures, informed the measures that we ran to assess collaboration [58-60]. 
The key network measures we use in our analysis are in-degree centrality and betweenness. Degree centrality is useful to depict an organization's number of reported ties (in-degree), or number of organizations they collaborate with (out-degree) [60]. As we limited respondents to identifying five organizational collaborators, we solely focus on their in-degree values in our subsequent analysis. In-degree values are calculated based on the number of organizations that reported collaborating with another organization (e.g., $\mathrm{X}$ reported collaborating with $\mathrm{Y}$ ). Although we limited organizations to identifying five respondents, organizations could have an in-degree score larger than five as a result of more than five organizations also identifying them as collaborators. In addition to sizing nodes using their in-degree score, we also use betweenness centrality. Betweenness centrality measures the number of times a node lies on the shortest path between other nodes [60]. As a centrality measure, betweenness captures a node's position in the network with regard to how the node links to other nodes [61]. Therefore, we use betweenness to measure the central role that organizations play in distributing resources in Denver's food movement network, often between more structurally advantaged (e.g., funders/landowners) and disadvantaged groups (e.g., food movement non-profits, laborers, activists).

Moving iteratively between the qualitative data, network tables, and network diagrams detailed organizational resource exchange, the structure and experience of concession, and an overall understanding of the food movement network. As our discussion and analysis of Denver's food movement illuminates, our triangulation of methods and data provide a deep understanding of the role of organizations' collaborative niche in the network with respect to shaping collaborative concession. How organizations obtain, use, and exchange money, land, and labor is central to this process of movement mobilization.

\section{Results and Discussion}

Collaboration is a critical component of resource mobilization and social change in Denver's food movement. Yet, as we illustrate below, while collaboration often helps organizations access strategically important resources, relationships also entail certain concessions. This is because the ideological and structural attributes of the food movement network reflect and work to reproduce certain organizations' priorities, especially those with control of money and land.

The uneven distribution of resources operates through and structures the influence of certain collaborative niches (Table 1). These are not exhaustive of the various roles and relationships in the Denver food movement. However, the collaborative niches that we identify and discuss are the most salient and active, which we determined through our network and qualitative data analysis. In Section 4.1, we focus on collaborative niche and distributions of money to show how organizations navigate existing food system change agendas to carry out their goals. This is important for understanding the role that exchanges of land and labor come to play in the process of collaborative concession, which we discuss in Sections 4.2 and 4.3.

\subsection{Money: Navigating Food Movement (Funders') Agendas}

Money is one of the main resources that social movements use to advance their interests. Unsurprisingly, the money possessed by more affluent organizations enables the broader enactment of goals and agendas [62]. In our case, this shapes the direction that organizations collaboratively concede toward. In other words, the projects and collaborations that receive funding through grants, in-kind, donations, and/or payment for goods and services reflect the aims of organizations with money. The goals that are most relevant include creating local food systems that grow economic and community development, increase food production and the consumption of healthy food, and reduce food insecurity. Central organizations in Denver's food movement with access to greater financial resources, such as funders and successful non-profits, focus the most on these priorities. Yet, because of this financial inequity, there are organizational tensions that shape collaborative concession. 
When considering how financial status informs how organizations cluster around and navigate certain food movement priorities, centrality measures are useful to quantify the relative power that an actor has within a network based on their relations [60]. We size our nodes according to the quantity of these ties (in-degree). In-degree values are calculated based on the number of organizations who reported collaborating with another organization. The larger the node, the more central the organization is in the network (Figure 1). In sum, the average in-degree for organizations was 1.62, ranging from a score of 0 to 8 with only $6 \%$ of organizations having an in-degree score higher than six. In a network of 100 organizations, this illustrates that there are a few central organizations due to their extensive network connections.

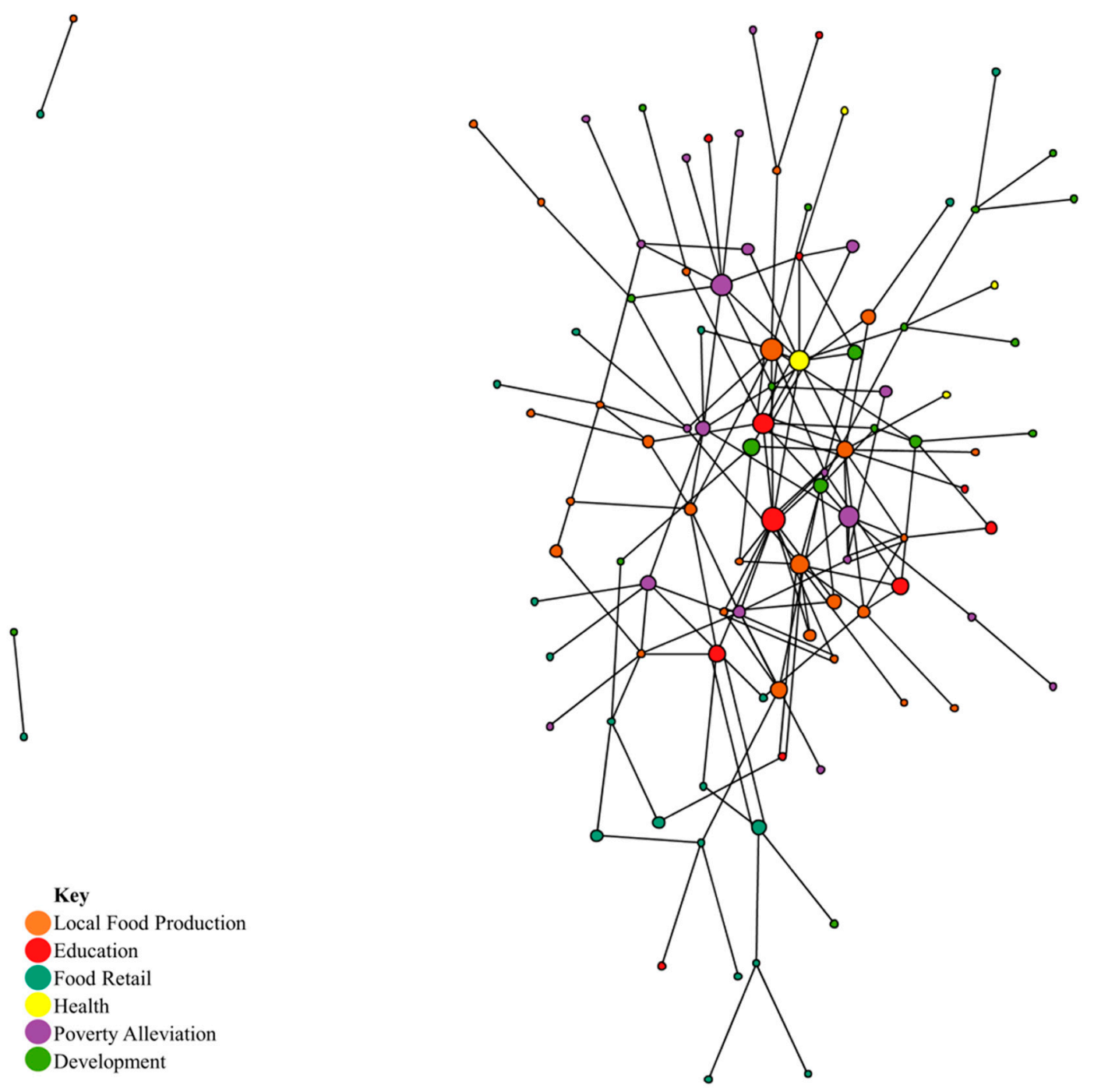

Figure 1. Organizations Sized by In-Degree and Colored by Collaborative Niche.

It is noteworthy that apart from one organization, the organizations with the most collaborations, between six and eight, also have budgets ranging from $\$ 2$ million to $\$ 100$ million (Table 2). These organizations include the Hunger Project, Healthy People, Community Seeds, Extend Education, and Gardens for the People, which work in poverty alleviation, health, local food production, and education collaborative niches. They have the capacity to build relationships and secure network influence by obtaining money from more financially powerful development entities, especially as it relates to focusing on the most politically palatable priorities, such as local food, food security, and diet, which are in city planning documents such as the Denver Food Vision. 
Table 2. Organization Budget, Collaborative Niche, and In-Degree Score (6-8).

\begin{tabular}{cccc}
\hline Organization & Niche & Budget Range (USD) & In-Degree Score \\
\hline Friendly Food Recovery & Poverty Alleviation & $0-100,000$ & 6 \\
Hunger Project & Poverty Alleviation & 2 mil-10 mil & 6 \\
Healthy People & Health & 2 mil-10 mil & 6 \\
Extend Education & Education & $10 \mathrm{mil}-100 \mathrm{mil}$ & 6 \\
Community Seeds & Local Food Production & $2 \mathrm{mil}-10 \mathrm{mil}$ & 7 \\
Gardens for the People & Education & $10 \mathrm{mil}-100 \mathrm{mil}$ & 8 \\
\hline
\end{tabular}

These collaborations are central to advancing certain movement agendas, but also reflect underlying network disparities. As illustrated through our social network measures, diagrams, tables, and interviews, the distribution of money is related to the number of network ties, as well as the collaborative niche. Navigating this network structure can require concessions that limit organizational independence. While collaborating helps overcome monetary deficits, it simultaneously reflects how financially powerful organizations inform movement priorities, which is often by playing a moderating role between other financially powerful organizations and those needing money. At the same time, having financial influence does not always equate to network centrality. While organizations such as the State Farm Department and Central City may have budgets spanning one billion dollars, they work in development-oriented collaborative niches that are not always seen as a critical partnership. What is important to consider here is both the financial budget and the collaborative niche in question as part of a process of collaborative concession involving a multiplicity of relationships. We can see this by cross-referencing Figure 1 with Tables 2 and 3 and putting this data in conversation with our interviews.

Table 3. Organization Budget, Collaborative Niche, and In-Degree Score (3-5).

\begin{tabular}{cccc}
\hline Organization & Niche & Budget Range (USD) & In-Degree Score \\
\hline Denver Cuisine & Food retail & $100,001-500,000$ & 3 \\
Mountainview Farm & Local food production & $100,001-500,000$ & 3 \\
Thriving Roots & Poverty alleviation & 2 mil-10 mil & 3 \\
New Perspective & Local food production & 2 mil-10 mil & 3 \\
State Farm Department & Development & 1 bil+ & 3 \\
Central City & Development & 1 bil+ & 3 \\
Local is Us! & Education & $0-100,000$ & 4 \\
Basil Farms & Local food production & $100,001-500,000$ & 4 \\
Farmers' Rights & Development & $500,001-2$ mil & 4 \\
Grow With Us & Local food production & $500,001-2$ mil & 4 \\
School District & Education & 1 bil+ & 4 \\
Denver Sustainability Partners & Local food production & $500,001-2$ mil & 5 \\
\hline
\end{tabular}

The experience of non-profit food movement organizations is particularly relevant. Since they are under pressure to apply for grants to subsidize their work, it is important for them to frame their initiatives in relation to popular food system change agendas. A typical example reflects the experience of Denver Sustainability Partners, which is a local food production (LFP) organization that represents the most common collaborative niche in Tables 2 and 3. They hire low-income youth of color to work on farms throughout the summer with government funding. With these grant subsidies also come concessions due to the limitations imposed by funders. Tom, one of their staff, detailed the challenge of relying on grant funding:

"Since we're a non-profit, we're really at the will of our funders, and historically, we have been very heavily dependent on foundation support, so a lot of private family foundations, a lot of Colorado-based foundations... We try to go after the kind of unrestricted funding that we can use however we want, but a lot of funders will only fund specific things. So, that's kind of an institutional pressure on us, to conform to what those institutions want us to do." 
Other respondents echoed this sentiment, adding that having funders requires complying with goals and metrics of success that do not necessarily mirror their own, which is a tension that subsequently drives collaborative concession. Complicating this further is that many grassroots-oriented community projects lack the capacity to navigate the bureaucracy of the grant process. For example, several development organizations use job creation, green marketing, or financial sustainability as indicators of success, and often aim for projects to be sustainable through the sales of produce. Whether it be government departments, land developers, or non-profit organizations working to advance housing and jobs, these organizations that support the food movement prioritize providing resources to initiatives that advance community economic development. As Meredith, a respondent from Basil Farms, reflected, "Developers and city folks have the most influence. They have resources that we want. They have money and they have the law in their pocket and they have land and they just have access."

Similarly, powerful funders act as gatekeepers to money and make determinations about their use on a local level. Many smaller grassroots organizations struggled to meet the metrics imposed by grants. For others, evaluation metrics were a mismatch with the work. Joanna, the founder of an organization called SunTime Farm, shared:

“But we've only been doing it for a few years. Of course, it's going to be slow going on your [funder] metrics. Like there's a lot of things that are coming into play. We're not these huge organizations that have had years ... We're just figuring this out. So, I think that that's kind of unfortunate. So, I can see that on the institution level of like if we're going to continue to do this work, how do we fund it?"

Ultimately, SunTime Farm merged with another non-profit organization, which is listed in Table 3, due to limited financial and staff capacity. This suggests that monetary inequities, as an expression of treasuring certain food movement organizations' practices and values over others, can restrict organizational success, at least from the perspective of being able to autonomously carry out a mission. Moreover, collaborations with key funders appears critical to overall organizational success and longevity.

Relatedly, local government also structures the types of projects that collaborations can work on by supplying money, as well as staffing and policy capacity, to advance a particular vision of food system change. Therefore, the influence of local government is part of the process of collaborative concession, as organizations often rely on the local government for funding, which in turn shapes their organizational mission. This also means that food movement organizations must learn how to sit at the city's table. A representative named Oscar who works for the city claimed:

"But the stakeholders who really get in there and roll up their sleeves and do work .... Those are the stakeholders who have the most influence. Now, granted, when you're bringing $\$ 200,000$ to the table, you're going to have some influence. But money in and of itself does not give you the influence. It's the money when it's tied to real, kind of, activities and projects that are going to make a difference in that area ... . [We have] some influence, we're a stakeholder, but the monies that we're providing are really going to groups that are making the difference."

The city's involvement in the food movement interacts with other network dynamics around access to financial support. If an organization can win grants, they can do more work, which can increase their probability of having influence with the city.

When studying food movement networks, it is important to consider how different organizations access money based on their relative connections with other organizations and networks and how that network position can be contingent on the continued acquisition of money. Consequently, many funders are likely central, as Figure 1 and Tables 2 and 3 suggest. When asked about who is most influential in Denver's food movement, Stanley from New Perspective asserted, "It's often the people with the money. I think foundations definitely have a lot of influence in urban agriculture ... it's kind of up to them which projects succeed or at least which projects get that initial influence to allow them to succeed and which ones won't." This points to how organizations may have influence in the movement if they can access resources by making accommodations to align their work with funders. Then, the reliance 
on money can render those organizations without influential connections peripheral. Concessions are twofold: organizations must either fit their work to dominant expectations to access funding or muddle through with low organizational capacity due to a low budget. While collaborative concession can reduce budget constraints, it can also reduce autonomy and further relations of dependency. Land is a resource that reveals some of these dynamics.

\subsection{Land: Taming Urban Agriculture, Local Food, and Institutional Partnerships}

Land is a critical resource in food movement networks. Similar to many other cities that are advancing urban agriculture and local food, there is a tension in Denver between what is codified in policy and what is enacted to promote land access. While the focus on local food production is common in Denver's policy discourse, little has been done to secure land for LFP organizations. Indeed, the number of farms has plummeted in the past 50 years. As a result, organizations in our network whose primary work was in urban agriculture heavily relied on institutional partnerships with schools to access land. Schools are attracted to urban agriculture because of the potential for new teaching opportunities for students. This includes connecting young people to where food comes from in the hopes of fostering healthy habits, contributing to increased knowledge about the food system, and getting hands into the dirt. Schools are incentivized to work with LFP organizations because then, they at least appear to be innovative in food procurement, landscape maintenance, and education. As we detail below, the process of collaborative concession operates through precarious land access and inequitable exchanges of risk, capital, and decision-making capacity.

We observe this process with betweenness centrality measures (Figure 2). As betweenness captures a node's position in the network in relation to how it links to other nodes [61], this measure can illustrate the role of "bridgers" in mobilizing resources. Therefore, betweenness is useful to show how resource flows often move through networks, because certain organizations have the capacity to link others to certain needs such as land. This seems to be especially the case for organizations that occupy the education collaborative niche. The more that a node connects organizations, the higher its betweenness score. In our case, standardized betweenness scores ranged from 0 to 7.42 . Only $16 \%$ of organizations had a standardized betweenness score higher than 1, illustrating that there are a few highly central organizations that act as resource conduits in the network.

Of the top 10 organizational betweenness scores, two were education organizations, one was a development organization, and four were LFP organizations that secured land through educational and government networks. For example, Community Seeds, Asher Farms, Basil Farms, and Denver Sustainability Partners were all highly ranked in terms of betweenness scores (3.4, 2.9, 2.6, and 1.4, respectively). Four of the top 10 organizations (Gardens for the People, Extend Education, Healthy People, and Community Seeds) also have some of the highest in-degree scores (Tables 2 and 3). One of the reasons for an organization's high betweenness score is the role of working with several institutional partners. In an interview with Community Seeds, David reinforced this idea as he highlighted the importance of developing institutional partnerships.

"I think the fact that we've grown a network, a very community-led and grassroots network .... I think one of our major successes came from a challenge that we faced early on in that we were leasing privately-owned land for community gardens, and we learned our lesson the hard way [they lost the land]. And we switched over to working with institutional partners; that has also added to our sustainability and longevity, where people can count on a garden being there from year to year."

Thus, not only did these partnerships help organizational longevity, they reflect a process of collaborative concession that includes learning from a negative land tenure experience that inspires a different kind of relationship through seeking to stabilize movement work with new resource exchanges across collaborative niches. 


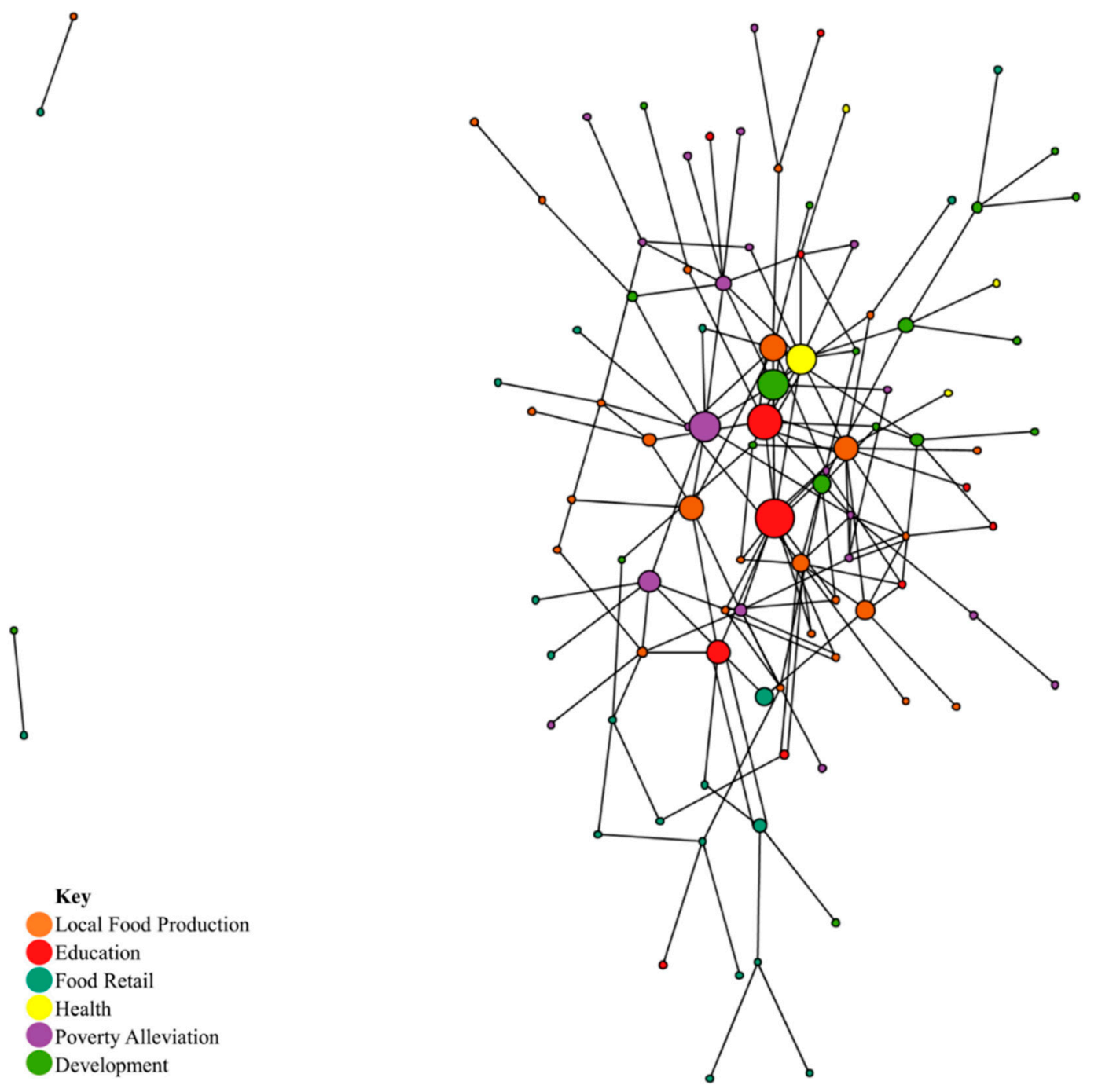

Figure 2. Organizations Sized by Betweenness and Colored by Collaborative Niche.

The hunt for land, as an extension of the need to meet broader movement goals and sustain different organizations' work, helps explain a key driver of collaborative concession. The precarity of this process compels partnerships with powerful institutional players such as schools, which unintentionally limits the power of landless organizations while simultaneously setting local food production parameters. In identifying why Basil Farms partners with public schools, Pam, the director, stated: "one of the driving forces behind partnering with a large institution was that it would kind of be like land in perpetuity". Throughout the interview, Pam stressed the importance of contracts with schools as pivotal in accessing this resource and therefore having a home base to secure grants. Other organizations in the network, such as Asher Farms, which is a local food production space at a different school, echoed the importance of maintaining institutional partnerships. Jeremiah, one of the founders, stated: "our approach to that is to really integrate ourselves as much at the school as possible in hopes that they see us as a more permanent partner and fixture to their campus". In fact, the tenuous nature of their land tenure was seen as central to their mission to provide educational agricultural opportunities that support local food production. By modifying their work to meet the desires of the school, they concede to the need for land to stay viable.

The contracts that govern many of these land tenure arrangements suggest that despite formal and informal expectations to use school spaces in certain ways, LFP organizations cope with the challenges embedded in the partnerships. Collaborative concessions often emerged due to tensions around safety issues and the subsequent navigation of institutional policies that hinder LFP organizations 
to advance their mission without oversight. For example, urban farmers often talked about school land as "underutilized land", which is a reference to space that was unsightly and costly to maintain. Schools could hand off maintenance costs and receive food, aesthetic improvement, and educational support. However, there are tensions over how such land should be maintained and what should be done with the food, which in turn shapes the responsibility for landscape aesthetics that often directly hinder the food production autonomy of LFP organizations. For instance, Kevin from Denver Sustainability Partners said, "the [School District] farms are very strict about how we can grow and distribute food". Thriving Roots, another organization that reflected on similar obstacles, echoed these issues, stating: "any time we would wanna do something like the compost bin [e.g., a problem of pests], or to build a shed [e.g., a hazard for children], there were all these rules put in place where you couldn't do it". While collaboration is often necessary to access land, this can come with complications.

There is also the issue of who is responsible for problems that arise when partnering with schools. As growing food comes with economic risks, these can exacerbate collaborative tensions. Michael, one of the founders of Fresh Food Denver, viewed unequal divisions of risk as a failure of these partnerships: "Well, [the School District], it's been very, very difficult to communicate with them, so for example, a hailstorm wipes out $60 \%$ of our crop. The risk was completely on Fresh Food Denver ... The risk was more on the farmer, even though they paid us to grow the food." Relatedly, some contracts also state that food can only go to school cafeterias instead of other markets; however, this can harm LFP organizations that are reliant on price premiums to pay labor, as school cafeteria budgets and policies struggle to accommodate these costs. These patterns illuminate that while there are reciprocal benefits of collaborating with educational institutions, such as the pertinent access to land, the burden of collaboration often falls on organizations that grow food.

However, the experiences of collaborative concession for those with high betweenness scores are not uniform. For a lot of the highly ranked organizations, possessing many resources mitigates concessions related to acquiring land. For example, while Housing for All is highly ranked in betweenness, it plays a unique role in the Denver food movement in terms of providing land to urban farmers. As it is a provider rather a receiver of land, the organization has more autonomy and more influence. On the other hand, LFP organizations that have high betweenness scores such as Denver Sustainability Partners and Basil Farms must be strategic in collaborating due to resource constraints, and thus are often limited in acquiring and using land. Thus, the role of organizations with high betweenness scores to act as conduits for land as a key resource is multifaceted throughout the food movement network, which reflects a dynamic process of collaboration that requires the taming of some organizations to operate in line with broader movement needs.

\subsection{Labor: The Uneven Relations of Work}

Sharing labor takes many forms, but as is similar with other Denver food movement collaborations, this resource can help achieve organizational goals and channel food activism in distinct ways. Over time, as organizations mobilize to share labor, uneven work relations become embedded within the network structure (e.g., to grow local food). Therefore, labor, especially of the volunteer kind, is an expression of the inequitable distribution of other resources such as money, which influences how organizations decide to collaborate. At a food movement network scale, this process maintains overall levels of activism, suggesting the importance of how interorganizational relations form around the differences between labor capacities and labor needs.

Below, we use two network maps in conversation with our qualitative data to illustrate how collaborative concession operates through the resource exchange of labor between the three most common sets of collaborative niches. The first set is represented in Figure 3, while the second and third set are represented in Figure 4. We size organizations by their in-degree score (Tables 2 and 3). The three sets are (1) poverty alleviation collaborations with LFP and food retail organizations; (2) LFP organizations and development organizations; and (3) LFP organizations and education organizations. 


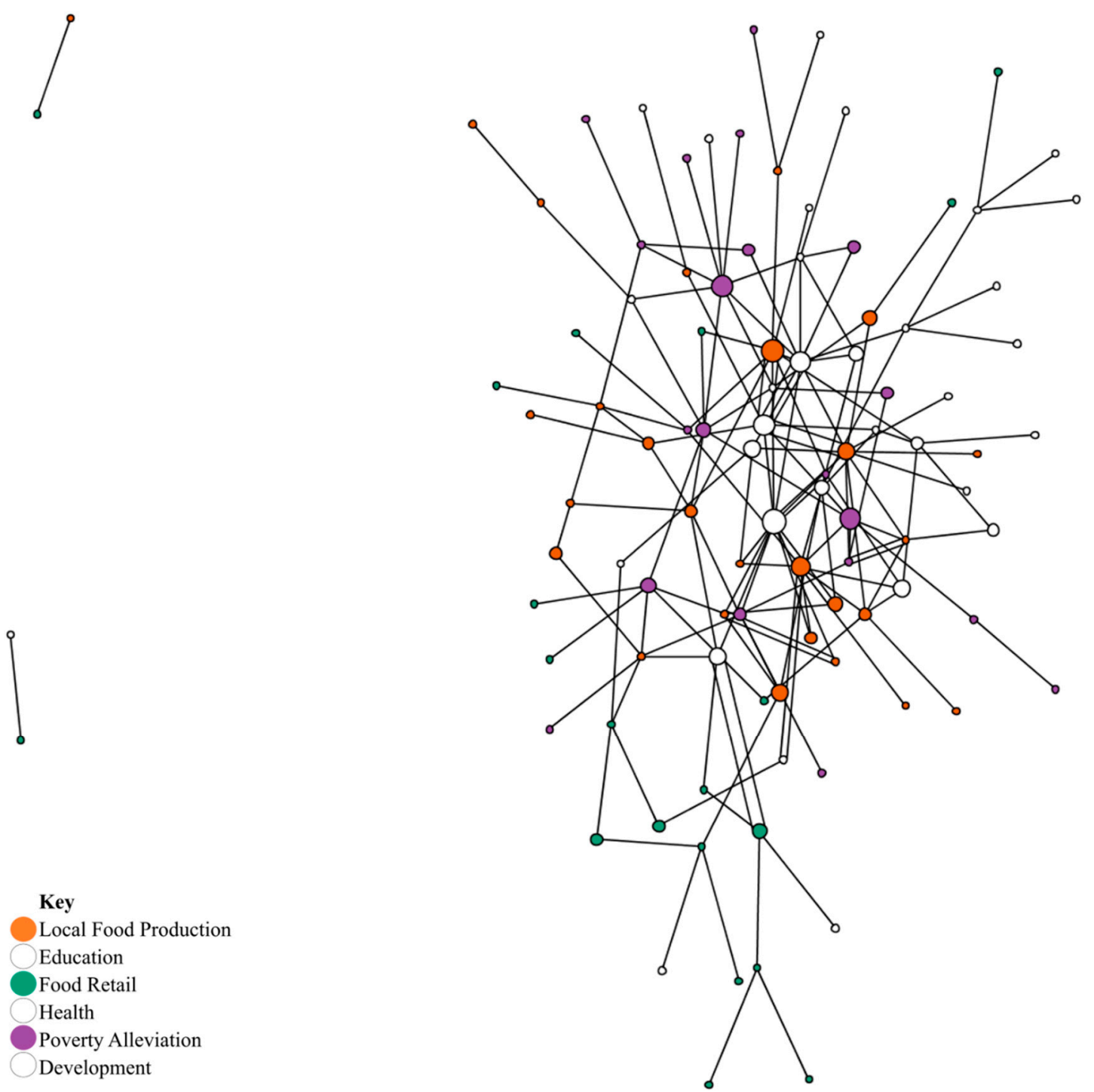

Figure 3. Collaboration Patterns between Local Food Production (LFP), Food Retail, and Poverty Alleviation Organizations.

First, poverty alleviation groups frequently collaborate with LFP and food retail organizations (Figure 3).

With political encouragement to both address food insecurity and generate economic growth, there is a hidden tradeoff in the form of undercompensated labor. As many of the LFP organizations are also non-profits, food donations are a common way for poverty alleviation organizations to rely on volunteer labor. This compels some resource-poor organizations to undertake labor that intervenes in the problem, however possible. These volunteer practices simultaneously reinforce collaborative concession, as organizations must rely on foundation funding and donations in order to sustain their work. As one participant with the poverty alleviation organization Friendly Food Recovery described:

"I'm the only paid employee at this point ... So we have about 30 volunteers who help out with various tasks ... I'd love to see Friendly Food Recovery [be] able to hire more employees. We're actually working on implementing a new program here coming up in the future that's sort of a new avenue to lowering barriers to healthy food, and that's by doing small-scale, low-cost, food redistribution of healthy food to corner stores in Denver."

Food retail organizations supply donated food, whereas poverty alleviation groups distribute donations through food banks, mobile markets, and free meals in community spaces. 


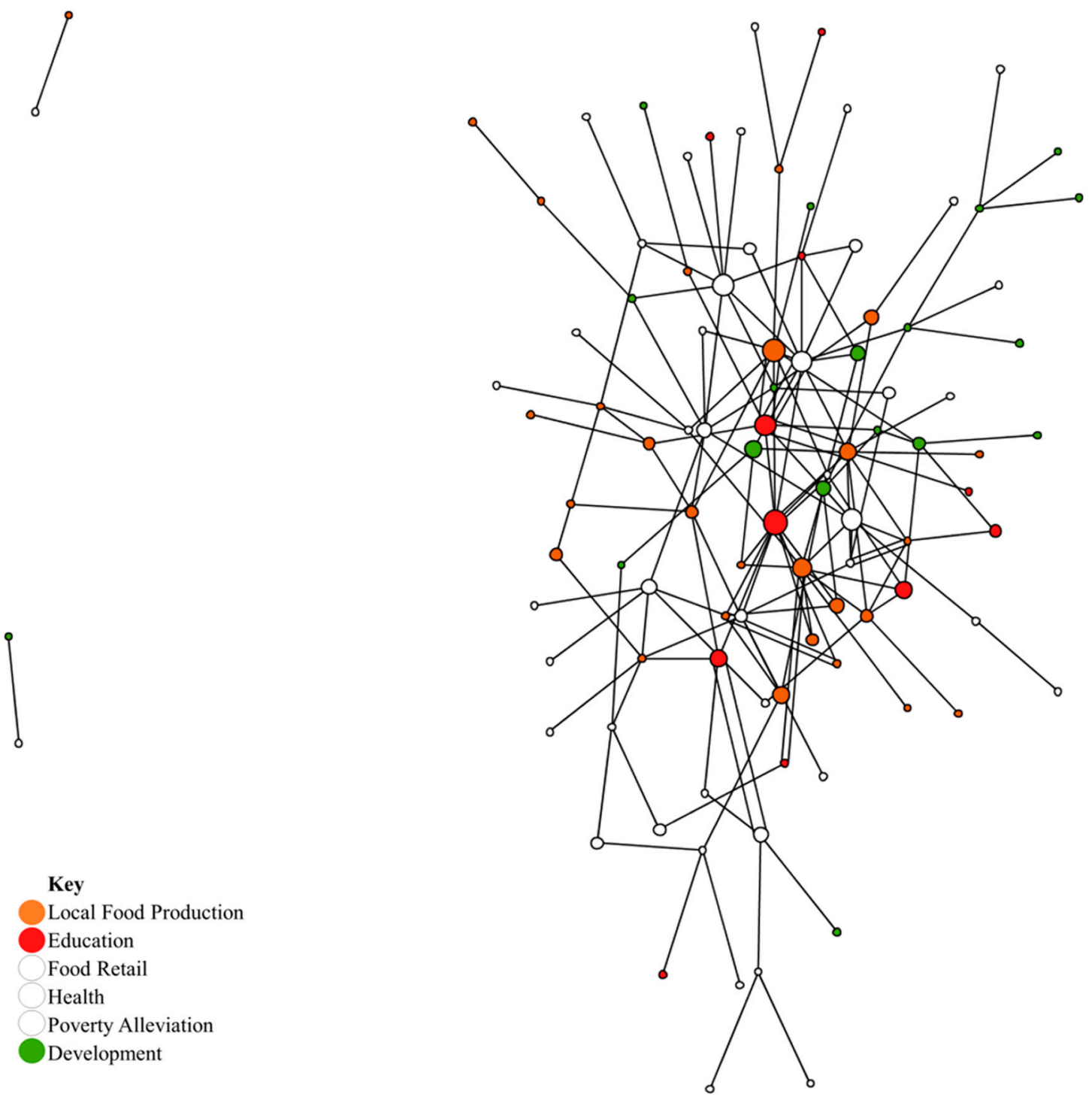

Figure 4. Collaboration Patterns between LFPs, Education, and Development Organizations.

Concession in collaborations can involve sacrificing pure politics for a pragmatic plan. Organizations acquire volunteer labor through listservs and social media, thus tapping into more privileged networks that have the time and inclination to support redistributing food that would otherwise go to waste. This makes sense in the context of small or constrained budgets for poverty alleviation groups. Veggies Now! and Local Food Rising, whose budgets are below $\$ 100,000$, use these strategies to connect with local farmers and gardeners to acquire surplus food, bringing their volunteers to the collaboration as a resource. Similarly, non-profits and grassroots organizations leverage their labor pools to support corporations that need to offload old food, but do not want to pay their own employees to do so. For example, Denver Food Retrieval works with several major business sectors. As one staff member plainly described this reliance, "We're dependent upon the catering industry [and sports, entertainment, and conference-hosting] in that sense."

Second, LFP organizations and development organizations frequently work together (Figure 4). A key practice driving collaborative concession is when development organizations work to convince their stakeholders of the value of this partnership, often by minimizing the need for their ongoing support due to partners working to become self-sustaining. For example, Housing for All collaborated with two LFP for-profits and one LFP non-profit. It leased land for five years until they could find a housing developer buyer. While the partnership was a short-term success in accessing land for the 
LFPs, it led to the eventual undermining of years of invested labor into beautifying the space and turning it into a zone of profitable food production. Despite the new developer's plan to include urban agriculture on site, these former tenants were not included. The housing entity, and the new upscale development, benefited from how the labor of LFPs helped revitalize a block in a gentrifying neighborhood. Therefore, such a development organization is influential in the food movement network by leveraging the labor of LFPs who need somewhere to grow food. A reliance on development organizations for land helps inch forward local food production goals overall-such as Denver's plan to grow and process at least $20 \%$ of the city's food from the state of Colorado-but hinders the longevity of individual LFPs when their labor investments are cut short or interrupted by insecure land arrangements.

Third, describing a similar dynamic of LFP organizations' labor driving community change within collaborations relates to work with education organizations (Figure 4). In this case, LFPs exchange undercompensated labor for money as they work on educational activities. This work attempts to accomplish the "unattainable trifecta" of urban agriculture, namely good food to those lacking access, job training for those excluded from employment opportunities, and income for producers [46]. For example, a representative from Fresh Food Denver explained, “One way we get around is we pay youth farmers through a non-profit called Denver Sustainability Partners who raises funds through [a government department] ... We hire kids to farm [public schools]." In contrast to representations of neoliberal food movement networks as compromised [18], a staff person at Denver Sustainability Partners notes that this kind of collaboration is necessary to align with a different public governance vision: "I like the private, public, non-profit partnership. Because the public entity has the land-there's so much land available in these school spaces. The private farmer-farmers deserve to get paid for their work. Then, we help provide both grant subsidies and labor subsidies in any way we can to offset, so the price per pound can be more competitive."

Food activists do not agree that this is the best way to mobilize the Denver food movement. Indeed, compromises associated with exchanging undercompensated labor for money in order to meet neoliberal expectations comes with hidden inequalities [45]. "I think we need to spend a lot of time really thinking about the funding structure," Andy from The Buzz pondered. "[W]e wouldn't be able to pay our crew or staff or anyone if we're really only depending on the income from the farm stand. And so that's a big challenge because we want our food to be accessible... But we know that for other food organizations, that that's not possible ... [B]ecause we get grants, we can set our produce for really cheap, but I worry that may be undermining other organizations that can't set their prices that low." Again, the self-organization of Denver's food movement network operates to sustain projects that accommodate for gaps in money that lead to free labor exchanges.

An overlapping collaborative concession is how to financially sustain school farms when there is not an adequate return on an organization's investment of resources. While some schools try to offset the disproportionate undercompensated labor that falls on LFPs by buying produce, LFPs can get more money for food by selling at markets or through community supported agriculture shares; food prices set by institutional food and nutritional service budgets are relatively low. These contradictory values lead to partnerships with institutional actors that are key to growing food, yet limit the financial gains of LFPs. Speaking to this process, Erin from Thriving Roots claimed, "I think there's a lot of willful ignorance around how expensive it is to grow food, just for the sake of saying, "Hey look, we're growing food on our land ... " I think that [the public school district] had a hard time recognizing how much labor they would've had to pay for if we didn't find these youth who were paid by [government funds] ... [W] were not bringing in any kind of skilled labor at all, and it was really difficult."

Our qualitative findings, coupled with a descriptive analysis of networked collaborative niches, highlight both the necessity and diversity of labor exchange in the Denver food movement. Organizations often acquire volunteer labor to carry out their work, which the uneven distribution of grant funding encourages. While this labor is critical to advancing certain food security and local food goals, it may simultaneously reinforce concessions such as activist burnout, the reduced cost of produce, 
underpaid employees, and tenuous market relationships. Therefore, the long-term sustainability of organizations and food movements that rely on the exchange of free labor is unclear [47].

\section{Conclusions}

Food movement networks reflect and shape resource-sharing patterns. These resources-especially money, land, and labor-are critical for food movement organizations to mobilize around a social change agenda. Yet, the resources alone do not explain the priorities of a food movement, which instead have more to do with how organizations are connected vis-à-vis the resources. Network ties are forms of collaboration predicated on organizational needs and mission commitments. On an interconnected network level, organizations with high centrality and high betweenness and those organizations that are connected to them not only mirror the collaborative priorities in the food movement, but also the necessary concessions to move forward. We refer to this process as collaborative concession. This may benefit the overall movement insofar as there is cohesion and clearly delineated goals. However, an uneven relational process is behind the outward representation of this focus.

As the case of Denver reveals, food movement organizations gel around several collaborative niches, which reflect key priorities. These include development, education, food retail, health, local food production, and poverty alleviation. In different combinations, organizations work across niches to accomplish missions. However, when looking at the content of collaborations, it is the case that not all organizational relations are created equal. For many of the food activists we interviewed, there is frustration and often disillusionment with the need to make concessions in order to accomplish short-term goals, let alone establish long-term organizational stability. What this suggests is that food movements perhaps self-organize through concessions. Sharing and acquiring resources is not inherently net positive, meaning that the food movement might require influential organizations to shape the agenda and then discipline the practices of organizations that without such a network tie would be isolated from the connections that are necessary for their survival.

While there are market pressures and goals that affect organizations within Denver's food movement, the work of the movement extends well beyond a typical "alternative food network". Instead, the range of food activism reflects the assemblage of initiatives and organizations into a "food movement network". For example, groups growing food or fighting hunger do not simply work to create or rely on alternative economic arrangements to achieve their goals; there are also political engagements and social commitments that inform their practices. The inclusive approach to food activism that we take in this article opens up the possibility for nuanced understandings of how food movements mobilize.

One way that future research can study the assemblage of diverse practices is to determine the strategic use of concessions in food movement networks by examining the relationships between different types of concessions and food movement outcomes. Such work may help contribute to improving practice, especially for those challenging influential organizations in a food movement to address more peripheral concerns. Relatedly, our study suggests the need to pay attention to the particular collaborative niches around which organizations prioritize their work. It is likely that different sociohistorical realities inform niche emergence and change, and therefore, the specific kinds of food activism that are deemed important. Future research should also consider the role of different resource exchanges such as time and knowledge. There is also an opportunity to begin understanding transnational ties and the networked dimensions of international food movements, such as the food sovereignty movement. After all, the basis for food system change rests in the ability of an array of food activists and organizations to mobilize resources to collaborate into networked configurations, even if this comes with strategic concessions.

Author Contributions: Conceived and designed project one, formal analysis-J.S.; Data collection, methodology, and formal analysis-I.L.; Conceived, designed, and collected data project two, formal analysis-J.H.; Formal analysis-K.R.; Review and editing-J.S., I.L., J.H. and K.R. 
Funding: The first author received funding to conduct much of this research from a Faculty Development Fund Award for Outstanding Research and Creative Activity given by the College of Liberal Arts at Colorado State University. The research conducted by the third author was funded through a Center for Collaborative Conservation fellowship at Colorado State University.

Acknowledgments: We would like to first thank all the people who participated in this study. The breadth of your collaborative experiences and perspectives were critical to understanding some of the overall dynamics and particularities of the Denver food movement. Thank you to Jeni Cross in the Department of Sociology at Colorado State University for offering some useful feedback early on about framing some of our network findings. We also would like to extend our gratitude to Moya Kneafsey and Mustafa Hasanov for inviting us to write an article for this special issue. Thanks to Colorado State University Libraries Open Access Research and Scholarship Fund. Last, but certainly not least, we are grateful for the many constructive comments and suggestions made by the three anonymous reviewers. Any mistakes or oversights are our own.

Conflicts of Interest: The authors declare no conflict of interest.

\section{References}

1. Guthman, J. Neoliberalism and the making of food politics in California. Geoforum 2008, 39, 1171-1183. [CrossRef]

2. DeLind, L.B. Are local food and the local food movement taking us where we want to go? Or are we hitching our wagons to the wrong stars? Agric. Hum. Values 2011, 28, 273-283. [CrossRef]

3. Slocum, R. Whiteness, space and alternative food practice. Geoforum 2007, 38, 520-533. [CrossRef]

4. Reynolds, K.; Cohen, N. Beyond the Kale: Urban Agriculture and Social Justice Activism in New York City; University of Georgia Press: Athens, GA, USA, 2016.

5. Polletta, F. "Free spaces" in collective action. Theory Soc. 1999, 28, 1-38. [CrossRef]

6. Lichterman, P. Elusive Togetherness: Church Groups Trying to Bridge America's Divisions; Princeton University Press: Princeton, NJ, USA, 2005.

7. McCarthy, J.D.; Mayer, N.Z. Resource Mobilization and Social movements: A Partial Theory. Am. J. Sociol. 1977, 82, 1212-1241. [CrossRef]

8. Kriesi, H. The Organizational Structure of New Social Movements in a Political Context. In Comparative Perspectives on Social Movements; McAdam, D., John, D., McCarthy, J.D., Zald, M., Eds.; Cambridge University Press: Cambridge, UK, 1996; pp. 152-184.

9. Diani, M.; McAdam, D. Social Movements and Networks: Relational Approaches to Collective Action; Oxford University Press: Oxford, UK, 2003.

10. Diani, M. Introduction: Social Movements, Contentious Actions, and Social Networks: From Metaphor to Substance? In Social Movements and Networks: Relational Approaches to Collective Action; Diani, M., McAdam, D., Eds.; Oxford University Press: Oxford, UK, 2003; pp. 1-20.

11. Saunders, C. Using social network analysis to explore social movements: A relational approach. Soc. Mov. Stud. 2007, 6, 227-243. [CrossRef]

12. Levkoe, C.Z. The food movement in Canada: A social movement network perspective. J. Peasant Stud. 2014, 41, 385-403. [CrossRef]

13. Levkoe, C.Z.; Wakefield, S. Understanding contemporary networks of environmental and social change: Complex assemblages within Canada's 'food movement'. Environ. Polit. 2015, 23, 302-320. [CrossRef]

14. Holt-Giménez, E. Food Movements Unite! Strategies to Transform our Food Systems; Food First Books: Oakland, CA, USA, 2011.

15. Goodman, D.E.; DuPuis, M.; Goodman, M.K. Alternative Food Networks: Knowledge, Practice, and Politics; Routledge: New York, NY, USA, 2012.

16. van Bommel, K.; Spicer, A. Hail the snail: Hegemonic struggles in the slow food movement. Organ. Stud. 2011, 32, 1717-1744. [CrossRef]

17. Starr, A. Local Food: A Social Movement? Cult. Stud. Crit. Methodol. 2010, 10, 479-490. [CrossRef]

18. Alkon, A.H.; Mares, T.M. Food sovereignty in US food movements: Radical visions and neoliberal constraints. Agric. Hum. Values 2012, 29, 347-359. [CrossRef]

19. Constance, D.H.; Renard, M.C.; Rivera-Ferre, M.G. Alternative Agrifood Movements: Patterns of Convergence and Divergence; Emerald Group Publishing Ltd.: London, UK, 2014.

20. McClintock, M. Radical, reformist, and garden-variety neoliberal: Coming to terms with urban agriculture's contradictions. Local Environ. 2014, 19, 147-171. [CrossRef] 
21. Diani, M. The Cement of Civil Society: Studying Networks in Localities; Cambridge University Press: Cambridge, UK, 2013.

22. Ansell, C.K. Community embeddedness and collaborative governance in the San Francisco Bay Area environmental movement. In Social Movements and Networks: Relational Approaches to Collective Action; Diani, M., McAdam, D., Eds.; Oxford University Press: Oxford, UK, 2003; pp. 123-144.

23. Van Dyke, N.; McCammon, H. Strategic Alliances: Coalition Building and Social Movements; University of Minnesota Press: Minneapolis, MN, USA, 2010.

24. Loh, P.; Agyeman, J. Urban food sharing and the emerging Boston food solidarity economy. Geoforum 2019, 99, 213-222. [CrossRef]

25. Jarosz, L. The City in the County: Growing Alternative Food Networks in Metropolitan Areas. J. Rural Stud. 2008, 24, 231-244. [CrossRef]

26. Kloppenburg, J.; Hendrickson, J.; Stevenson, G.W. Coming in to the foodshed. Agric. Hum. Values 1996, 13, 33-42. [CrossRef]

27. Selfa, T.; Qazi, J. Place, taste, or face-to-face? Understanding producer-consumer networks in "local" food systems in Washington State. Agric. Hum. Values 2005, 22, 451-464. [CrossRef]

28. Christensen, L.O.; O'Sullivan, R. Using social networking analysis to measure changes in regional food systems collaboration: A methodological framework. J. Agric. Food Syst. Community Dev. 2015, 5, 113-129. [CrossRef]

29. Tregear, A. Progressing knowledge in alternative and local food networks: Critical reflections and a research agenda. J. Rural Stud. 2011, 27, 419-430. [CrossRef]

30. Knoke, D. Organizing for Collective Action; Aldine de Gruyter: New York, NY, USA, 1990.

31. Holt-Giménez, E. A Foodie's Guide to Capitalism: Understanding the Political Economy of what We Eat; Monthly Review Press: New York, NY, USA, 2017.

32. Sbicca, J. Food Justice Now! Deepening the Roots of Social Struggle; University of Minnesota Press: Minneapolis, MN, USA, 2018.

33. Levkoe, C.Z. Strategies for forging and sustaining social movement networks: A case study of provincial food networking organizations in Canada. Geoforum 2015, 58, 174-183. [CrossRef]

34. Bodin, Ö.; Crona, B.I. The role of social networks in natural resource governance: What relational patterns make a difference? Glob. Environ. Chang. 2009, 19, 366-374. [CrossRef]

35. Siegner, A.; Sowerwine, J.; Acey, C. Does Urban Agriculture Improve Food Security? Examining the Nexus of Food Access and Distribution of Urban Produced Foods in the United States: A Systematic Review. Sustainability 2018, 10, 2988. [CrossRef]

36. Penniman, L. The USDA Is Putting $\$ 34.3$ Million Into Local Food Projects. Will It Be Enough? Available online: https://www.yesmagazine.org/new-economy/the-usda-is-putting-34-3-million-into-localfood-projects-will-it-be-enough-20151113 (accessed on 7 January 2019).

37. Porter, C.; Wechsler, A. Follow the Money: Resource Allocation and Academic Supremacy among Community and University Partners in Food Dignity. J. Agric. Food Syst. Community Dev. 2018, 8, 63-82. [CrossRef]

38. Hinrichs, C.C. Embeddedness and local food systems: Notes on two types of direct agricultural market. J. Rural Stud. 2000, 16, 295-303. [CrossRef]

39. Hislop, R.S. Reaping Equity Across the USA: FJ Organizations Observed at the National Scale. Master's Thesis, University of California, Davis, CA, USA, 2015.

40. Alkon, A.H.; Kato, Y.; Sbicca, J. Back to the City: Food and Gentrification in North American; New York University Press: New York, NY, USA, forthcoming.

41. Alkon, A.H.; Cadji, J. Sowing Seeds of Displacement: Gentrification and Food Justice in Oakland, CA. Int. J. Urban Reg. Res. 2018. [CrossRef]

42. Joassart-Marcelli, P.; Bosco, F.J. Alternative Food and Gentrification: Farmers' Markets, Community Gardens and the Transformation of Urban Neighborhoods. In Just Green Enough: Urban Development and Environmental Gentrification; Curran, W., Hamilton, T., Eds.; Routledge: New York, NY, USA, 2018; pp. 92-106.

43. Sbicca, J. Urban Agriculture, Revalorization, and Green Gentrification in Denver, Colorado. Res. Polit. Sociol. 2019, 26, 143-164.

44. Sussman, L.; Bassarab, K. Food Policy Council Report 2016; Johns Hopkins University Center for a Livable Future: Baltimore, MD, USA, 2017. 
45. Galt, D.E. The Moral Economy is a Double-Edged Sword: Explaining Farmers' Earnings and Self-Exploitation in Community-Supported Agriculture. Econ. Geogr. 2013, 89, 341-365. [CrossRef]

46. Weiler, A.M.; Otero, G.; Wittman, H. Rock Stars and Bad Apples: Moral Economies of Alternative Food Networks and Precarious Farm Work Regimes. Antipode 2016, 48, 1140-1162. [CrossRef]

47. Daftary-Steel, S.; Herrera, H.; Porter, C.M. The unattainable trifecta of urban agriculture. J. Agric. Food Syst. Community Dev. 2015, 6, 19-32. [CrossRef]

48. Biewener, C. Paid work, unpaid work, and economic viability in alternative food initiatives: Reflections from three Boston urban agriculture endeavors. J. Agric. Food Syst. Community Dev. 2016, 6, 35-53. [CrossRef]

49. Saunders, C. Insiders, Thresholders, and Outsiders in West European Global Justice Networks: Network Positions and Modes of Coordination. Eur. Polit. Sci. Rev. 2014, 6, 167-189. [CrossRef]

50. Ernstson, H.; Sörlin, S.; Elmqvist, T. Social movements and ecosystem services-The role of social network structure in protecting and managing urban green areas in Stockholm. Ecol. Soc. 2008, 13, 39. [CrossRef]

51. Castells, M. The City and the Grassroots: A Cross-Cultural Theory of Urban Social Movements; University of California Press: Berkeley, CA, USA, 1983.

52. Jacobs, J. The Death and Life of Great American Cities; Vintage Books: New York, NY, USA, 1992.

53. DuBois, W.E.B. The Philadelphia Negro: A Social Study; Oxford University Press: Oxford, UK, 2007.

54. Engels, F. The Condition of the Working Class in England; Oxford University Press: Oxford, UK, 2009.

55. City of Denver. Denver Food Vision. Available online: https://www.denvergov.org/content/dam/denvergov/ Portals/690/Healthy\%20Food/FoodVision-draft122116.pdf (accessed on 10 February 2019).

56. Marsden, P.V. Recent developments in network measurement. In Models and Methods in Social Network Analysis; Carrington, P.J., Scott, J., Wasserman, S., Eds.; Cambridge University Press: Cambridge, UK, 2005; pp. 8-30.

57. Borgatti, S.P.; Everett, M.G.; Freeman, L.C. Ucinet for Windows: Software for Social Network Analysis; Analytic Technologies: Harvard, MA, USA, 2002.

58. Bidart, C.; Lavenu, D. Evolutions of personal networks and life events. Soc. Netw. 2005, 27, 359-376. [CrossRef]

59. Crossley, N.; Prell, C.; Scott, J. Social network analysis: Introduction to special edition. Methodol. Innov. Online 2009, 4, 1-5. [CrossRef]

60. Hanneman, R.A.; Riddle, M. Introduction to Social Network Methods. Available online: http://faculty.ucr. edu/ \{\}hanneman/ (accessed on 10 February 2019).

61. Giuffre, K. Communities and Networks: Using Social Network Analysis to Rethink Urban and Community Studies; Polity Press: Malden, MA, USA, 2013.

62. Nicholls, W. Place, networks, space: Theorising the geographies of social movements. Trans. Inst. Br. Geogr. 2009, 34, 78-93. [CrossRef]

(C) 2019 by the authors. Licensee MDPI, Basel, Switzerland. This article is an open access article distributed under the terms and conditions of the Creative Commons Attribution (CC BY) license (http://creativecommons.org/licenses/by/4.0/). 